\title{
Article
}

\section{Sustainable Urban Habitats: The Contributory Components of Viable Eco- Diverse Landscapes}

derbyshire, Alan

Available at http://clok.uclan.ac.uk/5162/

derbyshire, Alan (2010) Sustainable Urban Habitats: The Contributory Components of Viable Eco-Diverse Landscapes. International Journal of Environmental, Cultural, Economic and Social Sustainability, 6 (2). pp. 265276. ISSN ISSN: 1832-2077

It is advisable to refer to the publisher's version if you intend to cite from the work.

For more information about UCLan's research in this area go to http://www.uclan.ac.uk/researchgroups/ and search for <name of research Group>.

For information about Research generally at UCLan please go to http://www.uclan.ac.uk/research/

All outputs in CLoK are protected by Intellectual Property Rights law, including Copyright law. Copyright, IPR and Moral Rights for the works on this site are retained by the individual authors and/or other copyright owners. Terms and conditions for use of this material are defined in the policies page.

\section{CLoK}

Central Lancashire online Knowledge www.clok.uclan.ac.uk

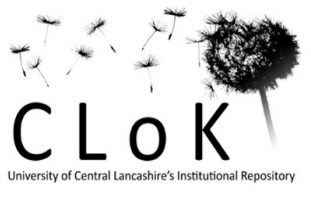


This study examines the conceptual, ecological and structural elements that contribute to the development of sustainable urban habitats. It is argued that the establishment of genuinely sustainable urban environments has been hampered by the lack of a clear and agreed definition of sustainable practices amongst building professions. Consequently, this has contributed to the maintenance of fuzzy ideology and practices regarding sustainability within built environment professions. This study reviews the threads that connect genuine aspirations for sustainable habitats within built environment professions and university design departments. It considers the reasons for the perceived lack of creativity when amalgamating relevant native species, ecological diversity and landscaping materials within UK city centers. The paper discusses the possible causes for the 'play it safe' approach to the design of green spaces, cites institutional and commercial innovations and outlines the potential for viable ecological design projects. 